\title{
UNEXPECTED FORMATION OF THE FIRST DOUBLY BENZYLIC 1,1-DI-GRIGNARD REAGENT
}

\author{
Henricus J. R. de Boer, Maarten Plugge, Otto S. Akkerman and Friedrich Bickelhaupt* \\ Scheikundig Laboratorium, Vrije Universiteit \\ De Boelelaan 1083, NL-1081 HV Amsterdam, The Netherlands <bicklhpt@chem.vu.ni>
}

\begin{abstract}
Reaction of 1-bromo-2-(1-chloro-1-trimethylsilylmethyl)benzene (3) with magnesium in THF expectedly gave the corresponding 1,3-di-Grignard reagent $1 \mathrm{~b}$ in $44 \%$ yield, but in addition, the isomeric 1,1-di-Grignard reagent 4 was obtained in equal amounts. Compound 4 is remarkable for two reasons: it is one of the few examples of a 1,1-di-Grignard reagent, and its formation involves rearrangement by 1,3-migration of a trimethylsilyl group which provides further evidence for the occurrence of carbanionic intermediates such as 11 during the formation reaction of Grignard reagents.
\end{abstract}

\section{INTRODUCTION}

Di-Grignard reagents $\mathrm{XMg}-\mathrm{Y}-\mathrm{MgX}$ are of interest for several reasons [1,2]. In the first place, they may be useful synthons because reaction with electrophiles leads to other difunctional derivatives; this is particularly attractive for the synthesis of a great variety of organometallic heterocycles. Secondly, they sometimes show unusual structures, in particular when the bridge -Y- connecting the two organomagnesium functions consists of three carbon atoms or less, the so-called "small" di-Grignard reagents $[3,4]$. Thirdly, these reagents often pose the challenge of not being easily accessible by the ordinary approaches, for instance the well-known Grignard reagent formation reaction of the corresponding dihalide with magnesium metal. For this reason, the number of known 1,1-di-Grignard reagents, which have two magnesium atoms attached to the same carbon, is rather limited [1,2].

Fortuitously, we came across such a species in the context of our investigations on the benzylic/aromatic 1,3-diGrignard reagent $1 \mathrm{a}$; it is connected by the well-known Schlenk equilibrium with the corresponding diorganylmagnesium compound 2a. The latter has been applied for the synthesis of a number of organometallic heterocycles $[1,2,5-11]$.

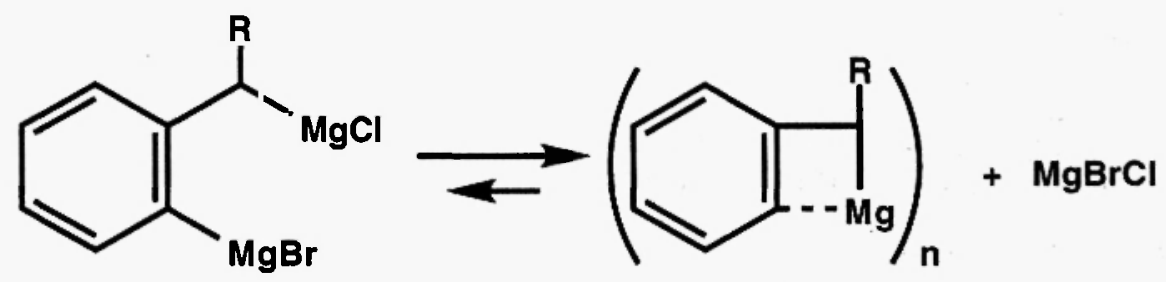

1

2
a: $\mathbf{R}=\mathrm{H}$
b: $\mathrm{R}=\mathrm{SiMe}_{3}$

Compound 2a is presumably oligomeric as it is poorly soluble in THF (about $0.004 \mathrm{M}$ ). On the one hand, this is convenient since $\mathbf{2 a}$ is easily obtained in pure form by simple decantation of the supernatant THF solution, but on the other hand, it is a disadvantage for certain applications and especially for investigations of its structure. For this reason, we undertook the synthesis of the trimethylsilyl analogues $\mathbf{1 b}$ and $\mathbf{2 b}$, respectively, in the hope that these substituted derivatives might show a better solubility.

\section{EXPERIMENTAL}

General

Solvents were freshly distilled from lithium aluminum hydride. The formation reactions of organomagnesium compounds were performed under argon. GLC analyses (hexamethylbenzene as internal standard) and purifications were performed on an Intersmat GC 120 (10\% OVI0I, 1/8", $1.75 \mathrm{~m}$, FID or $10 \%$ OVI01, 1/4", 1.5 
m, TCD). All products were were analyzed by GCMS on a Hewlett Packard 5360 mass spectrometer equipped with a Hewlett Packard 5890 gaschromatograph. High resolution mass spectra were recorded with a VARIAN MAT CH5 double focussing mass spectrometer operating at an ionization potential of $70 \mathrm{eV} .{ }^{1} \mathrm{H}$ and ${ }^{13} \mathrm{C}$ NMR spectra were recorded on a Bruker WM 250 spectrometer ( 250 and $63 \mathrm{MHz}$, respectively).

\section{l-Bromo-2-(l-chloro-l-trimethylsilylmethyl)benzene (3)}

By the method of Brandsma et al. [12], a solution of [-bromo-2-(chloromethyl)benzene [13] (7 g, $36.2 \mathrm{mmol}$; prepared from 2-bromobenzylalcohol [14] by the procedure of Landini et al. [15]) and chlorotrimethylsilane (4.7 g, $43.4 \mathrm{mmol})$ in THF $(18 \mathrm{~mL})$ was added at $-100{ }^{\circ} \mathrm{C}$ during $20 \mathrm{~min}$ to the solution of lithium diisopropylylamide $(36.2 \mathrm{mmol})$ in THF $(25 \mathrm{~mL})$. After $15 \mathrm{~min}$ at $-100^{\circ} \mathrm{C}$, the reaction mixture was warmed to RT during $45 \mathrm{~min}$, then water $(15 \mathrm{~mL})$ was added. The organic layer was separated and the aqueous phase was 3 times extracted with diethyl ether. The organic fractions were combined, washed with $2 \mathrm{~N} \mathrm{HCl}, \mathrm{IN} \mathrm{NaHCO}_{3}$ and water until neutral and dried on $\mathrm{MgSO}_{4}$. Then the solvent was evaporated and the residue distilled to give 3 as a colorless liquid $(6.5 \mathrm{~g}, 65 \%)$, bp. $91{ }^{\circ} \mathrm{C} / 3$ millibar. ${ }^{1} \mathrm{H}$ NMR $\left(\mathrm{CDCl}_{3}\right): 0.16\left(\mathrm{~s}, 9 \mathrm{H},{ }^{2} J(\mathrm{Si}, \mathrm{H})=7 \mathrm{~Hz}\right), 4.98(\mathrm{~s}, 1 \mathrm{H})$, $7.06\left(\mathrm{td}, 1 \mathrm{H},{ }^{3} J(\mathrm{H}, \mathrm{H})=7 \mathrm{~Hz},{ }^{3} J(\mathrm{H}, \mathrm{H})=1.5 \mathrm{~Hz}\right), 7.32\left(\mathrm{td}, 1 \mathrm{H},{ }^{3} J(\mathrm{H}, \mathrm{H})=7 \mathrm{~Hz},{ }^{4} J(\mathrm{H}, \mathrm{H})=1.5 \mathrm{~Hz}\right), 7.50(\mathrm{dd}, 1 \mathrm{H}$, $\left.{ }^{3} J(\mathrm{H}, \mathrm{H})=7 \mathrm{~Hz},{ }^{4} J(\mathrm{H}, \mathrm{H})=1.5 \mathrm{~Hz}\right), 7.53\left(\mathrm{dd}, 1 \mathrm{H},{ }^{3} J(\mathrm{H}, \mathrm{H})=7 \mathrm{~Hz},{ }^{4} J(\mathrm{H}, \mathrm{H})=1.5 \mathrm{~Hz}\right) .{ }^{13} \mathrm{C} \mathrm{NMR}\left(\mathrm{CDCl}_{3}\right):-3.2(\mathrm{q}$, $J(\mathrm{C}, \mathrm{H})=120 \mathrm{~Hz} ; J(\mathrm{C}, \mathrm{Si})=54 \mathrm{~Hz}), 50.6\left(\mathrm{~d} .{ }^{\prime} J(\mathrm{C}, \mathrm{H})=141 \mathrm{~Hz}\right), 122.3(\mathrm{bs}), 127.5\left(\mathrm{dd},{ }^{1} J(\mathrm{C}, \mathrm{H})=163 \mathrm{~Hz}\right.$, $\left.{ }^{3} J(\mathrm{C}, \mathrm{H})=8 \mathrm{~Hz}\right), 127.9\left(\mathrm{dd},{ }^{\prime} J(\mathrm{C}, \mathrm{H})=163 \mathrm{~Hz},{ }^{\prime} J(\mathrm{C}, \mathrm{H})=9 \mathrm{~Hz}\right), 129.6\left(\mathrm{dd},{ }^{2} J(\mathrm{C}, \mathrm{H})=161 \mathrm{~Hz},{ }^{3} J(\mathrm{C}, \mathrm{H})=7 \mathrm{~Hz}\right)$, $132.5\left(\mathrm{dd},{ }^{1} J(\mathrm{C}, \mathrm{H})=166 \mathrm{~Hz},{ }^{3} J(\mathrm{C}, \mathrm{H})=8 \mathrm{~Hz}\right), 140.0(\mathrm{bs}) . \mathrm{MS}: 276\left(1, \mathrm{M}^{+}\right), 203(1), 157(5), 89(16), 73(100)$. Found: C 43.03, $\mathrm{H}$ 5.11. Calc. for $\mathrm{C}_{10} \mathrm{H}_{14} \mathrm{BrClSi}$ : C 43.26, $\mathrm{H}$ 5.08.

\section{Reaction of 3 with magnesium}

A solution of 1,2-dibromoethane $(0.05 \mathrm{~g}, 0.25 \mathrm{mmol})$ in THF $(10 \mathrm{~mL})$ was added to triply sublimed magnesium $(1.30 \mathrm{~g}, 54.2 \mathrm{mmol})$. After stirring for $15 \mathrm{~min}$, a solution of $3(1.46 \mathrm{~g}, 5.8 \mathrm{mmol})$ in THF $(75 \mathrm{~mL})$ was added under vigorous stirring at RT during $4 \mathrm{~h}$; the reaction mixture turned yellowish brown. Stirring was continued for another $2 \mathrm{~h}$. After settling, the solution was syphoned from the excess of magnesium. Hydrolysis of a sample and titration with $\mathrm{HCl}$ and EDTA [16] revealed the presence of $10.2 \mathrm{mmol}$ of $\mathrm{OH}^{-}$and $10.6 \mathrm{mmol}$ of $\mathrm{Mg}^{2+}$, corresponding to about $90 \%$ of a dimagnesium reagent such as $1 \mathrm{~b}$ and/or 4 . This reaction mixture was quenched either with $\mathrm{D}_{2} \mathrm{O}$ or with chlorotrimethylstannane.

\section{$\mathrm{D}_{2} \mathrm{O}$ quench (5 and 6)}

To the reaction mixture described in the previous section, $\mathrm{D}_{2} \mathrm{O}$ (about $1 \mathrm{~mL}$ ) was added, followed by workup as described for 3. After evaporation of the solvent, a colorless liquid was obtained which was analyzed by GCMS; the products were separated by preparative GC. I-Deutero-2-(l-deutero-l-trimethylsilyl)methylbenzene (5). Colorless liquid, yield $44 \%$. ' $\mathrm{H}$ NMR $\left(\mathrm{CDCl}_{3}\right): 0.14\left(\mathrm{~s}, 9 \mathrm{H},{ }^{2} J(\mathrm{Si}, \mathrm{H})=6 \mathrm{~Hz}\right), 1.92\left(\mathrm{t}, 1 \mathrm{H},{ }^{2} J(\mathrm{H}, \mathrm{D})=2 \mathrm{~Hz}\right), 6.86$ $\left(\mathrm{dd}, 1 \mathrm{H},{ }^{3} J(\mathrm{H}, \mathrm{H})=7 \mathrm{~Hz},{ }^{4} J(\mathrm{H}, \mathrm{H})=1.5 \mathrm{~Hz}, 6.93\left(\mathrm{dt}, 1 \mathrm{H},{ }^{3} J(\mathrm{H}, \mathrm{H})=7 \mathrm{~Hz},{ }^{4} J(\mathrm{H}, \mathrm{H})=1.5 \mathrm{~Hz}\right), 7.04-7.11(\mathrm{~m}, 2 \mathrm{H})\right.$. ${ }^{3} \mathrm{C} \mathrm{NMR}\left(\mathrm{CDCl}_{3}\right)[17]:-1.9\left({ }^{1} J(\mathrm{C}, \mathrm{Si})=52 \mathrm{~Hz}\right), 26.9\left(\mathrm{t},{ }^{1} J(\mathrm{C}, \mathrm{D})=18 \mathrm{~Hz}\right), 123.8,128.0,128.1,140.5 . \mathrm{MS}: 166$ $\left(8, \mathrm{M}^{+}\right), 151(7), 93(4), 73(100)$. l, l-Dideuteromethyl-2-trimethylsilylbenzene (6). Colorless liquid, yield $44 \%$. ${ }_{\mathrm{H} \mathrm{NMR}}\left(\mathrm{CDCl}_{3}\right): 0.21\left(\mathrm{~s}, 9 \mathrm{H},{ }^{-} \mathrm{J}(\mathrm{Si}, \mathrm{H})=6 \mathrm{~Hz}\right), 2.31$ (quintet, $\left.1 \mathrm{H},{ }^{2} J(\mathrm{H}, \mathrm{D})=2 \mathrm{~Hz}\right), 7.05(\mathrm{~m}, 2 \mathrm{H}), 7.13(\mathrm{~m}, 1 \mathrm{H})$, $7.35(\mathrm{~m}, 1 \mathrm{H}) .{ }^{13} \mathrm{C} \mathrm{NMR}\left(\mathrm{CDCl}_{3}\right)[18]:-0.1\left({ }^{\mathrm{l}} J(\mathrm{C}, \mathrm{Si})=53 \mathrm{~Hz}\right), 22.6$ (quintet, $\left.{ }^{1} J(\mathrm{C}, \mathrm{D})=14 \mathrm{~Hz}\right), 124.9,129.1$, 129.7, 134.3, 138.4, 143.4. MS: $166\left(13, \mathrm{M}^{+}\right), 151(100), 122(21)$.

\section{Chlorotrimethylstannane quench (7 and 8 )}

To the reaction mixture obtained from 3 and magnesium as described above, a solution of $\mathrm{Me}_{3} \mathrm{SnCl}(11.2 \mathrm{mmol})$ in THF ( $5 \mathrm{~mL})$ was added, followed by workup as described for 3 . After evaporation of the solvent, a colorless liquid was obtained which was analyzed by GCMS; the products were separated by preparative GC. $1-(1$ Trimethylsilyl-1-trimethylstannyl)methyl-2-trimethylstannylbenzene (7). Colorless liquid, yield $44 \%$. 'H NMR: $0.05\left(\mathrm{~s}, 9 \mathrm{H},{ }^{2} J(\mathrm{H}, \mathrm{Si})=6 \mathrm{~Hz}\right),-0.03\left(\mathrm{~s}, 9 \mathrm{H},{ }^{2} J(\mathrm{H}, \mathrm{Sn})=50 \mathrm{~Hz}, 52 \mathrm{~Hz}\right), 0.18\left(\mathrm{~s}, 9 \mathrm{H},{ }^{2} J(\mathrm{H}, \mathrm{Sn})=52 \mathrm{~Hz}, 53 \mathrm{~Hz}\right), 1^{1}, 61$ $\left(\mathrm{s}, 1 \mathrm{H},{ }^{2} J(\mathrm{H}, \mathrm{Si})=8 \mathrm{~Hz},{ }^{2} J(\mathrm{H}, \mathrm{Sn})=62 \mathrm{~Hz}\right), 6.74-6.89(\mathrm{~m}, 2 \mathrm{H}), 7.03-7.09(\mathrm{~m}, 1 \mathrm{H}), 7.14-7.24(\mathrm{~m}, 1 \mathrm{H}) .{ }^{13} \mathrm{C}$ NMR $\left(\mathrm{CDCl}_{3}\right):-7.9\left(\mathrm{q},{ }^{1} J\left(\mathrm{C}_{3} \mathrm{H}\right)=128 \mathrm{~Hz}\right), 0.5\left(\mathrm{q},{ }^{1} J(\mathrm{C}, \mathrm{H})=120 \mathrm{~Hz}\right), 29.2\left(\mathrm{~d},{ }^{2} J(\mathrm{C}, \mathrm{H})=112 \mathrm{~Hz}\right), 122.4(\mathrm{~d}$, $\left.{ }^{2} J(\mathrm{C}, \mathrm{H})=158 \mathrm{~Hz}\right), 126.4\left(\mathrm{~d},{ }^{2} J(\mathrm{C}, \mathrm{H})=156 \mathrm{~Hz}\right), 128.6\left(\mathrm{~d},{ }^{2} J(\mathrm{C}, \mathrm{H})=161 \mathrm{~Hz}\right), 136.3\left(\mathrm{~d},{ }^{2} J(\mathrm{C}, \mathrm{H})=154 \mathrm{~Hz}\right), 140.2$ (s), 151.8 (s). l-Trimethylsilyl-2-[l,l-bis(trimethylstannyl)methyl]benzene (8). Colorless liquid. yield $44 \%$. $\%$. H NMR: $-0.01\left(\mathrm{~s}, 18 \mathrm{H},{ }^{2} J(\mathrm{H}, \mathrm{Sn})=50 \mathrm{~Hz}, 52 \mathrm{~Hz}\right), 0.19\left(\mathrm{~s}, 9 \mathrm{H},{ }^{\circ} J(\mathrm{H}, \mathrm{Si})=6 \mathrm{~Hz}\right), 2.12\left(\mathrm{~s}, 1 \mathrm{H},{ }^{\prime} J(\mathrm{H}, \mathrm{Sn})=59 \mathrm{~Hz}\right.$, $61 \mathrm{~Hz}), 6.74-6.89(\mathrm{~m}, 2 \mathrm{H}), 7.03-7.09(\mathrm{~m}, \mathrm{IH}), 7.17-7.24(\mathrm{~m}, 1 \mathrm{H}){ }^{10} \mathrm{C} \mathrm{NMR}\left(\mathrm{CDCl}_{3}\right):-7.9(\mathrm{q}, \quad J(\mathrm{C}, \mathrm{H})=128$ $\mathrm{Hz}), 0.4\left(\mathrm{q},{ }^{\prime} J(\mathrm{C}, \mathrm{H})=118 \mathrm{~Hz}\right), 19.8(\mathrm{~d}, \cdot(\mathrm{C}, \mathrm{H})=121 \mathrm{~Hz}), 121.4(\mathrm{~d}, \mathrm{i} /(\mathrm{C}, \mathrm{H})=166 \mathrm{~Hz}), 127.0\left(\mathrm{~d},{ }^{i} J(\mathrm{C}, \mathrm{H})=160\right.$ $\mathrm{Hz}), 129.4\left(\mathrm{~d},{ }^{\prime} J(\mathrm{C}, \mathrm{H})=155 \mathrm{~Hz}\right), 134.6\left(\mathrm{~d},{ }^{1} J(\mathrm{C}, \mathrm{H})=164 \mathrm{~Hz}\right), 140.2(\mathrm{~s}), 154.2(\mathrm{~s})$. [19,20]). Mixture 7/8. MS: $492\left(3, \mathrm{M}^{+}\right), 477(2), 312(61), 297(57), 223(9), 165(100), 150(10), 135(57), 120(9), 105(7), 73(57)$. Found: C 39.35, H 6.28. Calc. for $\mathrm{C}_{16} \mathrm{H}_{32} \mathrm{SiSn}_{2}$ : C 39.23, H 6.58. 


\section{RESULTS AND DISCUSSION}

In line with our initial expectation, the synthesis of $\mathbf{1 b}$ from the corresponding dihalide 3 and sublimed magnesium in THF was achieved (Scheme 1); this follows from derivatization with deuterium oxide and chlorotrimethylstannane which furnished 5 and 7 , respectively, in $44 \%$ yield. However, these products were accompanied by an equal amount of their regioisomers 6 and 8 , respectively; these stem from the isomeric diGrignard reagent 4 which must result from a rearrangement involving migration of the trimethylsilyl group from the benzylic position to ortho-position with (formally) concomitant migration of the magnesium functionality.<smiles>[2H]c1ccccc1C([2H])C</smiles>

5<smiles>[2H]C([2H])c1ccccc1[SiH3]</smiles>

6<smiles>CC(Cl)c1ccccc1Br</smiles>

3

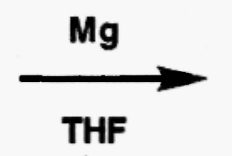

THF<smiles>CC(C)c1ccccc1N</smiles>

1b<smiles>Cc1ccccc1C(C)(Cl)Br</smiles>

$+\mathrm{Me} \mathrm{S}_{3} \mathrm{CI}$<smiles>CSc1ccccc1C(C)S(C)(C)C</smiles>

7<smiles>CSC(C)c1ccccc1S(C)(C)C</smiles>

8

Scheme 1

While from a preparative point of view, it was somewhat disappointing that a mixture of two Grignard reagents was obtained, it was highly rewarding for the following reasons. In the first place, it furnished another 
representative from the rare group of 1,1 di-Grignard reagents, namely 4 ; as a 1,1-dibenzylic dimagnesium species, it is to our knowledge the first example of this structural type. Secondly, the presence of 4 furnished evidence once again for the intermediacy of a carbanion in the process of formation of the Grignard reagent:

$$
\mathrm{R}-\mathrm{X}+\mathrm{Mg} \rightarrow \mathrm{R}-\mathrm{Mg}-\mathrm{X}
$$

Considerable progress has been achieved in the past decades concerning the mechanism of this simple looking reaction which, in reality, turned out to be rather complex and hence fascinating. Reduced to its most simple form and leaving out many conceivable and actually occurring side reactions, this mechanism is depicted in Scheme 2.

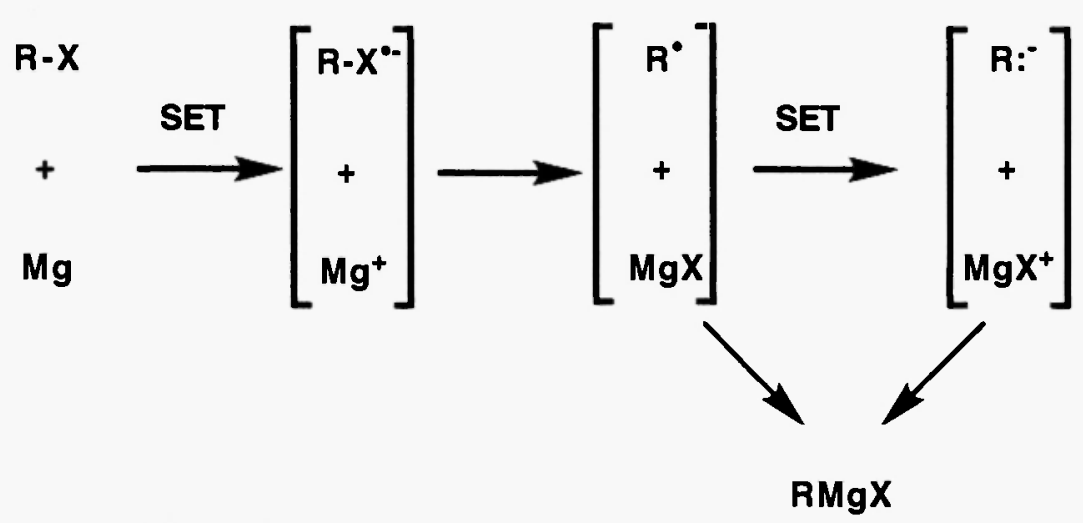

Scheme 2

It is generally agreed that radicals $\mathrm{R} \cdot$ play an important role as intermediates, although there is still some controversy concerning their exact nature and behavior [21,22]. The radicals are formed by single electron transfer (SET) from the magnesium metal to the organic halide RX under formation of radical anions $\mathrm{R}^{*}$. Especially in the aliphatic series, these radical anions will be transition states rather than short-lived intermediates and directly dissociate to give radicals $\mathrm{R} \cdot$ and the magnesium subhalide $\mathrm{MgX}$; both species will combine to furnish the Grignard reagent $\mathrm{RMgX}$.

While in most cases, this may be the predominant pathway, we have been able to provide evidence that at least in certain cases, the corresponding carbanions $\mathrm{R}^{-}$may be involved. They are formed from the radicals $\mathrm{R} \cdot$ by a second SET from the metal surface; combination of $\mathrm{R}^{-}$with $\mathrm{MgX}^{+}$then gives the same final product $\mathrm{RMgX}$. This was concluded from reactions which have no analogy in radical chemistry, but are quite characteristic for the behavior of carbanions. Besides typical cases of proton abstractions in crown ether chemistry [23], the rearrangement of organotin functionalities exclusively during, but not after the Grignard formation process [24] can best be explained by the intermediate formation of a carbanion. Transferred to the present case, a plausible course of events is shown in Scheme 3.

One may, somewhat arbitrarily, assume that the benzylic chlorine function is the most reactive one and thus the first stage of the reaction would lead to the mono-Grignard reagent 9; however, the sequence of events is not essential for the essence of the proposed mechanism. From 9, the usual double SET leads (via the radical 10) to the carbanion 11 and finally to the expected, unrearranged product $\mathbf{l b}$. Alternatively, 11 may react by attack of its carbanion functionality on silicon under formation of the silicate intermediate 12. Recently, there have been several pieces of evidence for such silicates involving pentacoordinate silicon with four or five carbon ligands [25-27]. Silicate 12 will preferentially cleave the benzylic bond [28] because this leads to the stable benzylic carbanion 13, which finally combines with $\mathrm{MgX}^{+}$to furnish 4 . This rationalization parallels that proposed for the migration of the trimethyltin unit from the benzylic to the ortho-position observed on reaction of 1-chloro-2(trimethylstannylmethyl)benzene with magnesium [24]. As indicated above, formation of ate complexes of Group 14 elements is typical for carbanionic species such as organolithium reagents [20-24], whereas radical intermediates behave differently $[22,24]$. 


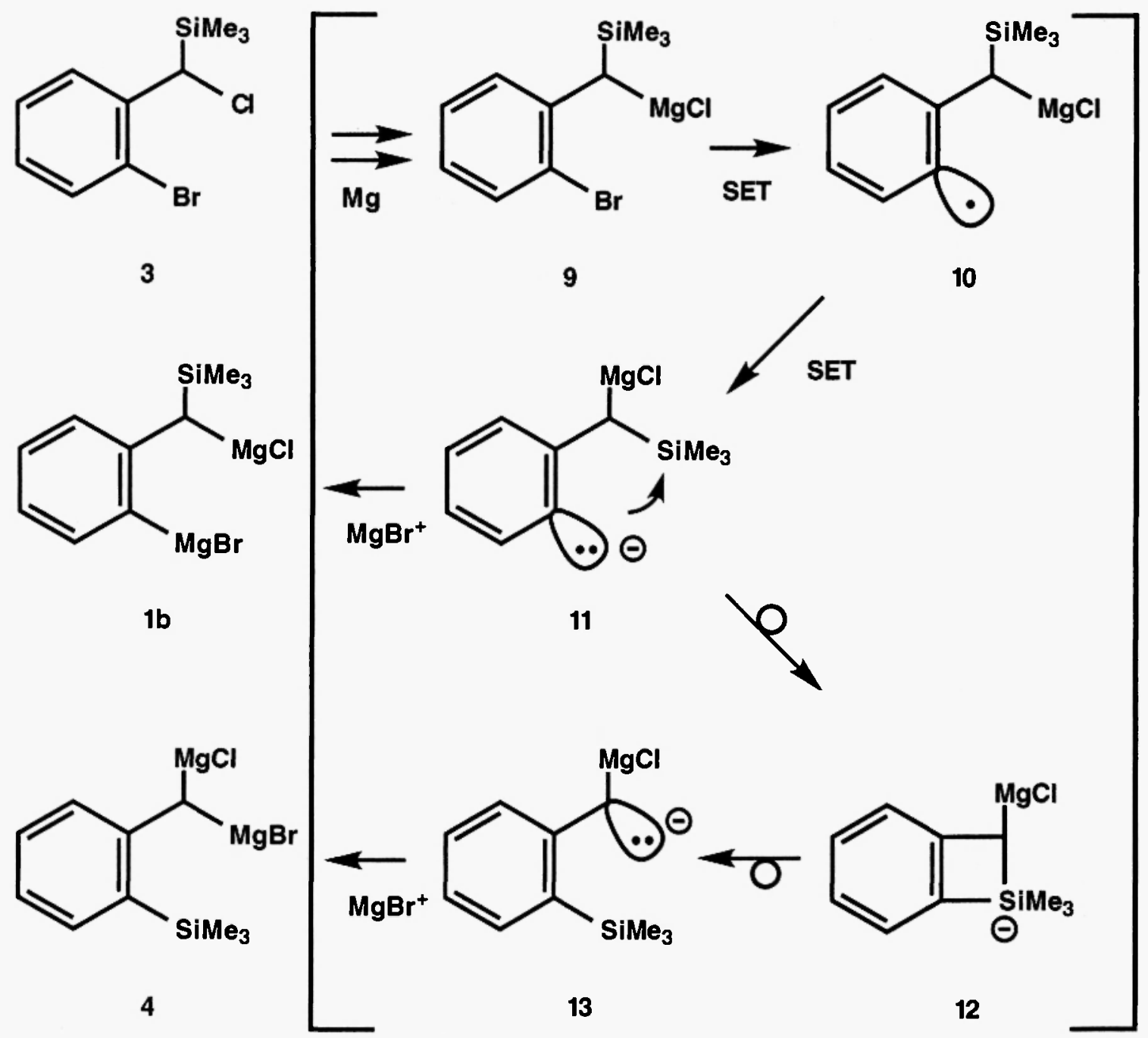

\section{Scheme 3}

\section{CONCLUSION}

The doubly benzylic di-Grignard reagent 4 is formed in $44 \%$ yield as one of the products in the reaction of the 1,3-dihalide 3 with magnesium. It is the first 1,1-di-Grignard of this type, and its formation presents a new piece of evidence for the intermediacy of carbanions in the Grignard reaction.

\section{REFERENCES}

[1] K. C. Kennon and G. R. Krow in Handbook of Grignard Reagents, G. S. Silverman and P. E. Rakita, Ed., Marcel Dekker, New York, 1996, 497-526.

[2] F. Bickelhaupt in Grignard Reagents, New Developments, H. G. Richey, Ed., Wiley, Chichester, $2000367-$ 393.

[3] H. L. Uhm in Handbook of Grignard Reagents, G. S. Silverman and P. E. Rakita, Ed., Marcel Dekker, New York, 1996, 117-144.

[4] F. Bickelhaupt in Grignard Reagents, New Developments, H. G. Richey, Ed., Wiley, Chichester, $2000299-$ 328.

[5] H. J. R. de Boer, O. S. Akkerman, F. Bickelhaupt, G. Erker, P. Czisch, R. Mynott, J. M. Wallis and C. Krüger, Angew. Chem., 1986, 98, 641; Angew. Chem. Int. Ed. Engl., 1986, 25, 639. 
[6] H. J. R. de Boer, O. S. Akkerman and F. Bickelhaupt, J. Organomet. Chem., 1987, 321, 291.

[7] H. J. R. de Boer, O. S. Akkerman and F. Bickelhaupt in Organometallic Syntheses, R. B. King and J. J. Eisch, Ed., Elsevier, Amsterdam, 1988, Vol. 4, 396-398.

[8] H. J. R. de Boer, B. J. J. van de Heisteeg, M. Flöel, W. A. Herrmann, O. S. Akkerman and F. Bickelhaupt, Angew. Chem, 1987, 99, 88; Angew. Chem. Int. Ed. Engl,. 1987, 26, 73.

[9] H. J. R. de Boer, O. S. Akkerman and F. Bickelhaupt, J. Organomet. Chem., 1987, 336, 447.

[110] H. J. R. de Boer, B. J. J. van de Heisteeg, G. Schat, O. S. Akkerman and F. Bickelhaupt, J. Organomet. Chem., 1988, 346, 197.

[11] H. J. R. de Boer, G. Schat, O. S. Akkerman, F. Bickelhaupt, M. de Wit and A. L. Spek, Organometallics, $1989,8,1288$.

[12] H. Andringa, Y. Heus-Koos and L. Brandsma, J.Organomet. Chem., 1987, 336, C41.

[13] G. L. Goerner and R. C. Nametz, J. Am. Chem. Soc., 1951, 73, 2940.

[14] S. Meyerson, P. N. Rylander, E. L. Eliel and J. P. McCollum, J. Am. Chem. Soc., 1959, 81, 2606.

[15] D. Landini, F. Monetari and F. Rolla, Synthesis, 1974, 37.

[16] A. D. Vreugdenhil and C. Blomberg, Recl. Trav. Chim. Pays-Bas, 1963, 82, 453, 461.

[1.7] W. Adcock, D. P. Cox and W. Kitching, J. Organomet. Chem., 1977, 133, 393.

[118] J. Schraml, V. Chvalovsky, M. Mägi, E. Lippmaa, R. Calas, J. Dunogues and P. Bourgeois, J.Organomet. Chem., 1976, 120, 41 .

[19] W. Adcock, B. D.Gupta, W. Kitching and D. Dodrell, J. Organomet. Chem., 1975, 102, 297.

[20] M. Bullpit, W. Kitching, W. Adcock and D. Dodrell, J. Organomet. Chem., 1976, 116, 161.

[21] C. Hamdouchi and H. M. Walborski in Handbook of Grignard Reagents, G. S. Silverman, P. E. Rakita, Ed., Marcel Dekker, New York, 1996, 145-218.

[22] J. F. Garst and F. Ungváry in Grignard Reagents, New Developments, H. G. Richey, Ed., Wiley, Chichester, 2000 185-275.

[23] P. M. Markies, O. S. Akkerman, F. Bickelhaupt, W. J. J. Smeets and A. L. Spek, J. Am. Chem. Soc., 1988, $110,4284$.

[24] H. J. R. de Boer, O. S. Akkerman and F. Bickelhaupt, Angew. Chem., 1988, 100, 735; Angew. Chem. Int. Ed. Engl., 1988, 27, 687.

[25] A. H. J. F. de Keijzer, F. J. J. de Kanter, M. Schakel, R. F. Schmitz and G. W. Klumpp, Angew. Chem., 1996, 108, 1183; Angew. Chem.. Int. Ed. Engl., 1996, 35, 1127.

[26] A. H. J. F. de Keijzer, F. J. J. de Kanter, M. Schakel, V. P. Osinga and G. W. Klumpp, J. Organomet. Chem., 1997, 548, 29.

[27] N. Rot, T. Nijbacker, R. Kroon, F. J. J. de Kanter, F. Bickelhaupt, M. Lutz and A. L. Spek, Organometallics, 2000, 19, 1319 and references cited.

[28] H. Gilman and W. H. Atwell, J. Am. Chem. Soc., 1964, 86, 5589.

Received: January 16, 2001 - Accepted: January 26, 2001 Accepted in publishable format: January 26, 2001 